\title{
The Effect of Consultant competence on the Project performance and Social-relational competence: focus on ICMCI competence framework
}

\author{
*Yong-Ki Hong, Ph.D. student, Dept. of Smart Convergence Consulting, Hansung University, ASI KR KS013 \\ Seoul,123biz@naver.com, \\ Yen-Yoo You, Professor, Division of Smart Management Engineering, Hansung University, ASI KR KSO13 \\ Seoul, threey0818@hansung.ac.kr, \\ Sang-Bong Kim, Professor, Division of Social Sciences, Hansung University, ASI KR KSO13 Seoul, \\ brainkim75@hansung.ac.kr \\ *Corresponding Author
}

\begin{abstract}
This research is to study the effect of consultant's competences on the project performance of consulting and social-relational competence of the consultant based on ICMCI competence framework. The survey was conducted, and the collected data were analyzed statistically. Descriptive statistics analysis, exploratory factor analysis, convergent validity, internal consistency reliability analysis and discriminant validity analysis using Smart-PLS 3.3.2 for measurement model analysis were performed. The importance and suitability of the path model were verified through the structural model analysis, and the evaluation of the effect size and the predictive suitability for the structural model were evaluated.

The results of this study are as follows. First, although the business competence and technical competence of consultant had a positive effect on the project performance, the effect of the values \& behavior competence on the project performance was not statistically significant. Second, the technical competence and the values \& behavior competence of consultant were found to have a positive effect on the social-relational competence, but the business competence had not a positive effect on the socialrelational competence. Third, social-relational competence of consultant was found to have a positive effect on the project performance, but the indirect effect of the consultant competence through socialrelational competence did not have a statistically significant effect on the project performance. This study is meaningful as a study to confirm that the social-relational competence affects the performance of consulting projects, but there is a limit to the generalization and application of results because it was targeted only at certified consultants.
\end{abstract}

Keywords: ICMCI competence framework, Business competence, Technical competence, Values and Behavior competence, Social-relational competence, Project performance

Received: 09.12.2020 $\quad$ Accepted: 14.01.2021 $\quad$ Published: 04.02.2021

\section{INTRODUCTION}

Since Korean government proposed a development plan to foster the knowledge service industry, the consulting market in Korea has grown both quantitatively and qualitatively, and society's perception of the value of knowledge services has also increased significantly. However, the domestic consulting market is still dominated by large overseas consulting companies, and the polarization among consulting companies is severe depending on the number of consultants and the size of the company. In fact, many SMEs consultants are having difficulty performing consulting, and in many cases, they are only concentrating on government-supported consulting projects. Although retired with long experience in other organizations, it is particularly difficult for consultants who are entering the consulting market without acquiring appropriate consulting techniques or skills, and they are not able to settle in the consulting market. In the meantime, research on competence of consulting had been conducted by various researchers, and through research, various consulting competence elements and competence models have been created. In this research, focused on the International Council of Management Consulting Institutes' competence framework (ICMCI competence framework), which consists of Business competence, Technical competence, Values \& Behavior competence as a Consultant competence, the purpose of this research is to study the effect of Consultant competence on the consultant's Social-relational competence and Project performance of consulting. 


\section{Theory and formula}

\subsection{Consultant competence}

The perspective of competence was initially the concept of competence at the individual level, but was defined as the psychological behavioral characteristics of individuals related to work performance as a broader meaning by McClelland (1973), a psychology professor at Harvard University [1]. In previous studies on consultant competence, some studies consisted of elements as ability, integrity and consideration, while others consisted of knowledge, ability and attitude, but the commonality of many studies is that competence is closely related to performance, unlike simple knowledge or competence. McClelland defined competences as "a bundle of outcomes" that appear through life, and after that Spencer (1993) described competences as 'basic traits that are naturally related to superior performance while being effective in a work or environment' [2]. Appelbaum \& Steed (2005) empirically analyzed the key success factors of the relationship between customers and consultants. In the study, it was confirmed that the consultant's expertise, understanding of customer crisis, clarity of the project purpose, and new problem solving ability of the project have a significant impact on the success of the consulting project [3]. The ICMCI competence framework that forms the basis of this study consists of three competences: Business competence, Technical competence and Values \& Behavior competence as shown in [Figure 1]. In addition, it consists of 8 competence classes, and the level required for consultant is divided into 3 levels according to skill level, and the competence required for each competence group is presented. This framework is said to require Client business insight and Consulting business insight as a Business competence, Functional specialization and Consulting skills as a Technical competence. It also suggests that Ethics \& professionalism, Analytical skills, Personal interaction and Personal development are necessary as a Values \& Behavior competence. Based on these competences, have a circular structure that Breadth of skills \& experience through Continued learning \& development feedback [4-5].

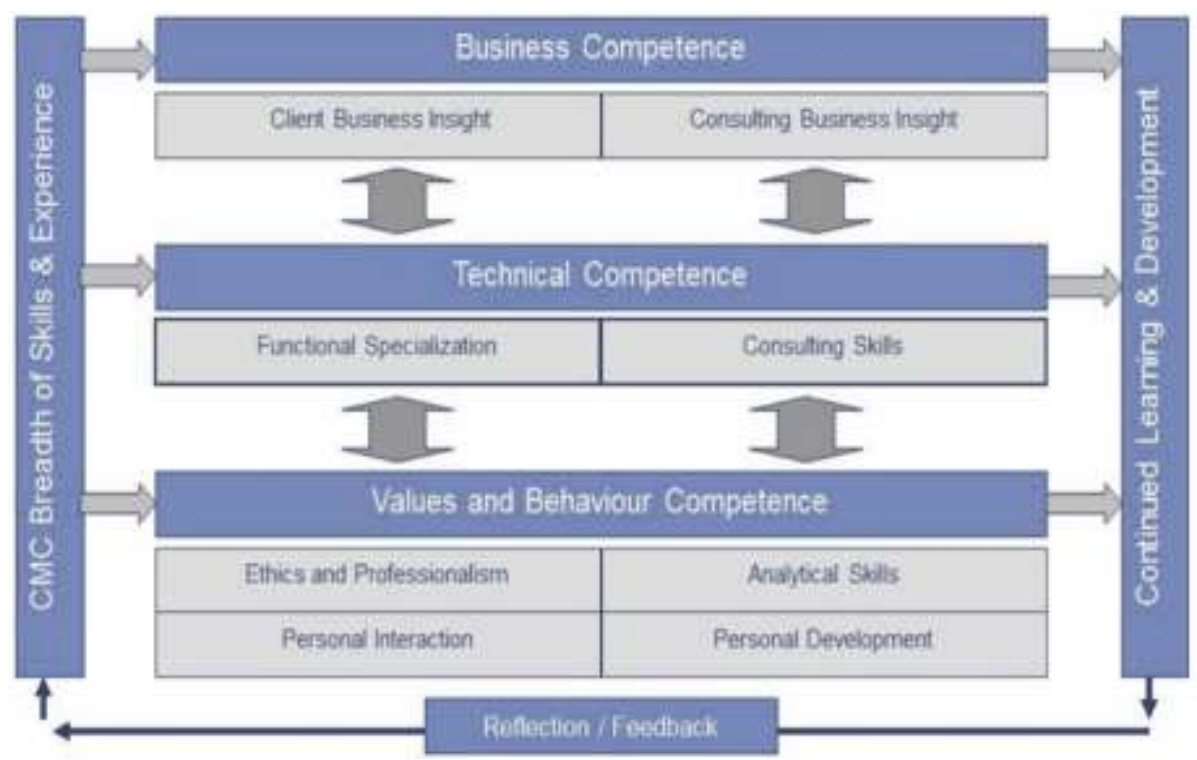

Figure 1. ICMCI Competence Framework

\subsection{Social-relational competence}

In the intelligent information society where the 4th industrial revolution and artificial intelligence technology are advanced, creative and fusion talent and relationship competence are required, and social-relational competence is the ability to communicate smoothly with community members and solve problems through collaboration. In order for a consultant to perform well in a project, it must have communication skills, empathy, and consideration based on trust. Communication skills can build trust while listening to, accepting, and coordinating each other's opinions, and naturally improve collective intelligence while carrying out projects [6]. A good social relationship requires not only recognizing other people's thoughts and actions, but also the ability to express themselves and others' feelings in language [7]. Consideration deeply related to social relationship competences is formed on the basis of empathy and trust, and benefits everyone according to the level of trust between relying parties [8].

\subsection{Project Performance}

The performance of a consulting project is defined as achieving the project objectives within a given 
budget and a set project period, and performance measurement is divided into the performance of the process and the outcome of the project. The former focuses mainly on the process point of view and measures cost, time, target quality, etc., while the latter focuses on the quality of the final outcome through the project [9]. Kerzner (1984) suggested period compliance, budget compliance, predicted performance achievement, customer satisfaction and utilization as factors for measuring consulting performance [10], Pinto \& Prescott (1990) argued that project proponents must satisfy both internal factors such as organizational considerations such as duration and budget, and external factors such as customer satisfaction [11].

\section{Experimental setup}

\subsection{Research Model}

The basis of the research model was adopted as Consultant competence, Social-relational competence and Project performance. As suggested in previous studies and ICMCI, Business competence, Technical competence and Values \& Behavior competence were composed of sub variables of Consultant competence. In this study as shown in [Figure 2], Consultant competence was configured as an independent variable, Social-relational competence as a parameter, and Project performance as a dependent variable.

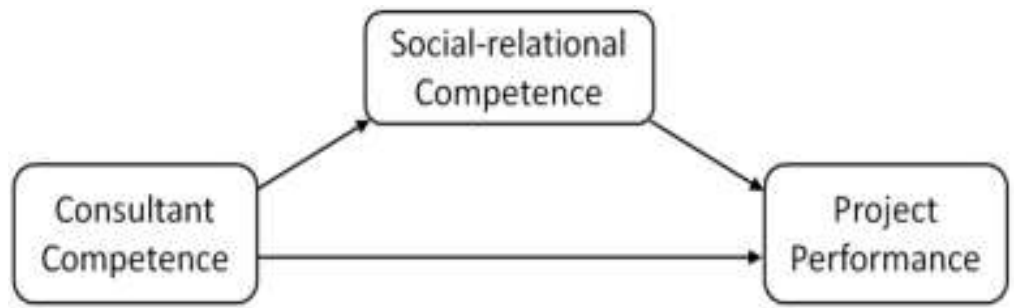

Figure 2. Research model

\subsection{Hypothesis}

H1. Consultant competence will have a positive effect on Project performance.

H2. Consultant competence will have a positive effect on Social-relational competence.

H3. Social-relational competence will have a positive effect on Project performance.

H4. Social-relational competence will mediate between Consultant competence and Project performance.

\subsection{Operational Definition of Variables}

As shown in [Table 1] the operational definition of each variable is summarized.

Table 1. Operational Definition of Variables

\begin{tabular}{|c|c|c|c|}
\hline \multicolumn{2}{|c|}{ Latent variables } & Operational Definition & Researcher \\
\hline $\begin{array}{l}\text { Consultant } \\
\text { competence }\end{array}$ & $\begin{array}{l}\text { Business } \\
\text { competence }\end{array}$ & $\begin{array}{l}\text { The ability to apply practical knowledge such as } \\
\text { business and environmental awareness based on } \\
\text { customer's business and consulting business insights } \\
\text { - customer's business understanding } \\
\text { - awareness of the external environment } \\
\text { - consulting business knowledge } \\
\text { - understanding the commercial aspects of the } \\
\text { implementation process }\end{array}$ & {$[1-5]$} \\
\hline
\end{tabular}




\begin{tabular}{|c|c|c|c|}
\hline & $\begin{array}{l}\text { Technical } \\
\text { competence }\end{array}$ & $\begin{array}{l}\text { Core consulting technologies, tools and functions used } \\
\text { by consultants to provide professional services to } \\
\text { customers } \\
\text { - sector knowledge and experience } \\
\text { - determining customer requirements } \\
\text { - customer contact management } \\
\text { - applying expertise to create customer value } \\
\text { - risk and problem management }\end{array}$ & \\
\hline & $\begin{array}{l}\text { Values \& Behavior } \\
\text { competence }\end{array}$ & $\begin{array}{l}\text { Combination of professional values and technologies to } \\
\text { provide services to current and future customers based } \\
\text { on ethics and professionalism } \\
\text { - act ethically } \\
\text { - acting as an expert } \\
\text { - take responsibility for your actions } \\
\text { - communication effectively with participants } \\
\text { - self-development }\end{array}$ & \\
\hline $\begin{array}{l}\text { Social-relational } \\
\text { competence }\end{array}$ & & $\begin{array}{l}\text { Ability to communicate smoothly with community } \\
\text { members and solve problems through collaboration } \\
\text { - communication awareness and skills } \\
\text { - ability to empathize other people's thoughts and } \\
\text { feelings } \\
\text { - consideration or benevolence between relying parties }\end{array}$ & [6-8] \\
\hline $\begin{array}{l}\text { Project } \\
\text { performance }\end{array}$ & & $\begin{array}{l}\text { Achieving the project objectives within a given budget } \\
\text { and a set project period, etc. } \\
\text { - term compliance } \\
\text { - finish to project within budget } \\
\text { - solve the problem presented by the customer } \\
\text { - overall customer satisfaction }\end{array}$ & [9-11] \\
\hline
\end{tabular}

\section{Result discussions}

\subsection{Demographic Analysis}

The total number of samples used in this study was 176 , and frequency analysis was conducted to determine the demographic characteristics of the samples. As a result of analysis, the gender composition was 155 male consultants (87.8\%), 21 female consultants (12.2\%); it appeared that most of the respondents were male consultants. The age of the consultants appeared $50 \mathrm{~s}$ was 68 people (38.8\%), 40 s was 49 people $(27.5 \%), 60$ s or older was 34 people $(19.4 \%)$, and 30 s or less was 25 people $(14.3 \%)$. The consulting career it appeared 56 people (31.6\%) with more than 5 years and less than 10 years, 50 people $(28.6 \%)$ with more than 3 years and less than 5 years, 39 people $(22.4 \%)$ with more than 10 years, and 31 people $(17.4 \%)$ with less than 3 years, in that order.

\subsection{Descriptive Statistics Analysis, Exploratory Factor Analysis}

As a result of descriptive statistics analysis to examine the normality of the collected data, it was confirmed that individual measurement variables form a normal distribution with a standard deviation of 3 or less, a kurtosis and a skewness each absolute value of 3 or less. In order to verify the validity of the variables, exploratory factor analysis was conducted on the sub-variables of the Consultant competence: Business competence, Technical competence, and Values \& Behavior competence, and also exploratory factor analysis on Social-relational competence and Project performance. In the factor 
analysis process, the observation variables VC2, BC5, and VC1 which inhibit the convergent validity and internal consistency reliability of the research model, were sequentially removed.

\subsection{Measurement Model Analysis}

For the measurement model test in this study, convergent validity, internal consistency reliability and discriminant validity tests were conducted. The convergent validity is checked based on the factor loading value, the reliability for each measurement variables and average variance extraction (AVE). The internal consistency reliability is tested by the Cronbach's $\alpha$ value and composite reliability.

\subsubsection{Convergent Validity and Internal Consistency Reliability Analysis}

As shown in [Table 2], the factor loading value was higher than the recommended level of 0.7 , and the reliability and AVE by measurement variables were higher than the recommended level of 0.5 . Internal consistency reliability was tested by the Cronbach's $\alpha$ value and composite reliability. Cronbach's $\alpha$ value for latent variables exceeded the recommended level of 0.6 or higher, and the composite reliability was also higher than the recommended level of 0.6 or higher.

Table 2. Results of Measurement Model Analysis

\begin{tabular}{|c|c|c|c|c|c|c|c|}
\hline \multirow{3}{*}{$\begin{array}{l}\text { Latent } \\
\text { variables }\end{array}$} & \multirow{3}{*}{$\begin{array}{l}\text { Observation } \\
\text { variables }\end{array}$} & \multicolumn{3}{|c|}{ Convergent validity } & \multicolumn{3}{|c|}{ Internal consistency reliability } \\
\hline & & $\begin{array}{l}\text { Factor } \\
\text { loading }\end{array}$ & $\begin{array}{l}\text { Variable } \\
\text { reliability }\end{array}$ & AVE & Cronbach's $\alpha$ & $\begin{array}{l}\text { Rho_A } \\
\left(\rho_{A}\right)\end{array}$ & $\begin{array}{l}\text { Composite } \\
\text { reliability }\end{array}$ \\
\hline & & p.708 & $>.50$ & $>.50$ & $.60 \sim .90$ & $>.70$ & $.60 \sim .90$ \\
\hline \multirow{4}{*}{$\begin{array}{l}\text { Business } \\
\text { competence }\end{array}$} & $\mathrm{BC} 1$ & .851 & 0.724 & \multirow{4}{*}{.723} & \multirow{4}{*}{.873} & \multirow{4}{*}{.884} & \multirow{4}{*}{.912} \\
\hline & $\mathrm{BC} 2$ & 877 & 0.769 & & & & \\
\hline & $\mathrm{BC} 3$ & .798 & 0.637 & & & & \\
\hline & $\mathrm{BC} 4$ & .872 & 0.760 & & & & \\
\hline \multirow{4}{*}{$\begin{array}{l}\text { Technical } \\
\text { competence }\end{array}$} & $\mathrm{TC} 1$ & .865 & 0.748 & \multirow{4}{*}{.718} & \multirow{4}{*}{.869} & \multirow{4}{*}{.873} & \multirow{4}{*}{.910} \\
\hline & $\mathrm{TC} 2$ & .877 & 0.769 & & & & \\
\hline & TC3 & .835 & 0.697 & & & & \\
\hline & $\mathrm{TC} 4$ & .810 & 0.656 & & & & \\
\hline \multirow{3}{*}{$\begin{array}{l}\text { Values \& } \\
\text { Behavior } \\
\text { competence }\end{array}$} & VC3 & .728 & 0.530 & \multirow{3}{*}{.618} & \multirow{3}{*}{.691} & \multirow{3}{*}{.722} & \multirow{3}{*}{.828} \\
\hline & VC4 & .877 & 0.769 & & & & \\
\hline & VC5 & .745 & 0.555 & & & & \\
\hline \multirow{5}{*}{$\begin{array}{l}\text { Social- } \\
\text { relational } \\
\text { competence }\end{array}$} & SC1 & .762 & 0.581 & \multirow{5}{*}{.689} & \multirow{5}{*}{.886} & \multirow{5}{*}{892} & \multirow{5}{*}{.917} \\
\hline & SC2 & .833 & 0.694 & & & & \\
\hline & SC3 & .897 & 0.805 & & & & \\
\hline & SC4 & .794 & 0.630 & & & & \\
\hline & SC5 & .857 & 0.734 & & & & \\
\hline \multirow{3}{*}{$\begin{array}{l}\text { Project } \\
\text { performance }\end{array}$} & PP1 & .762 & 0.581 & \multirow{3}{*}{688} & \multirow{3}{*}{.886} & \multirow{3}{*}{.892} & \multirow{3}{*}{.917} \\
\hline & PP2 & .838 & 0.702 & & & & \\
\hline & PP3 & .804 & 0.646 & & & & \\
\hline
\end{tabular}




\begin{tabular}{|l|l|l|}
\cline { 2 - 3 } PP4 & .898 & 0.806 \\
\hline PP5 & .840 & 0.706 \\
\hline
\end{tabular}

\subsubsection{Discriminant Validity Analysis}

Discriminant validity is confirmed by comparing the correlation between the square root value of the Average variance extraction (AVE) for each variable and other variables based on Fornell and Larker's theory. As shown in [Table 3], the correlation coefficient of all variables was smaller than the AVE square root value, and discriminant validity was secured.

Table 3. Discriminant Validity of the Measurement model

\begin{tabular}{|c|c|c|c|c|c|}
\hline Latent Variables & $\begin{array}{l}\text { Business } \\
\text { competence }\end{array}$ & $\begin{array}{l}\text { Technical } \\
\text { competence }\end{array}$ & $\begin{array}{l}\text { Values \& \& } \\
\text { Behavior } \\
\text { competence }\end{array}$ & $\begin{array}{l}\text { Social- } \\
\text { relational } \\
\text { competence }\end{array}$ & $\begin{array}{l}\text { Project } \\
\text { performance }\end{array}$ \\
\hline $\begin{array}{l}\text { Business } \\
\text { competence }\end{array}$ & .850 & & & & \\
\hline $\begin{array}{l}\text { Technical } \\
\text { competence }\end{array}$ & .432 & .847 & & & \\
\hline $\begin{array}{l}\text { Values \& Behavior } \\
\text { competence }\end{array}$ & .274 & .579 & .786 & & \\
\hline $\begin{array}{l}\text { Social-relational } \\
\text { competence }\end{array}$ & .263 & .480 & .475 & .830 & \\
\hline $\begin{array}{l}\text { Project } \\
\text { performance }\end{array}$ & .561 & .640 & .551 & .569 & .829 \\
\hline
\end{tabular}

Annotation: The diagonal bold letter is AVE square root.

\subsection{Structural Model Analysis}

\subsubsection{Multicollinearity}

As shown in [Table 4], the result of examining the internal VIF values for evaluating the multicollinearity between the latent variables for each endogenous latent variable, all of them were less than 5.0, confirming that there was no multicollinearity.

Table 4. Results of Multicollinearity evaluation between Latent variables

\begin{tabular}{l|l|l|l|l|l}
\hline Latent Variables & $\begin{array}{l}\text { Business } \\
\text { competence }\end{array}$ & $\begin{array}{l}\text { Technical } \\
\text { competence }\end{array}$ & $\begin{array}{l}\text { Values \& } \\
\text { Behavior } \\
\text { competence }\end{array}$ & $\begin{array}{l}\text { Social- } \\
\text { relational } \\
\text { competence }\end{array}$ & $\begin{array}{l}\text { Project } \\
\text { performance }\end{array}$ \\
\hline $\begin{array}{l}\text { Business } \\
\text { competence }\end{array}$ & & & 1.230 & 1.235 \\
\hline $\begin{array}{l}\text { Technical } \\
\text { competence }\end{array}$ & & & 1.712 & 1.827 \\
\hline $\begin{array}{l}\text { Values \& Behavior } \\
\text { competence }\end{array}$ & & & 1.506 & 1.628 \\
\hline $\begin{array}{l}\text { Social-relational } \\
\text { competence }\end{array}$ & & & & 1.412 \\
\hline
\end{tabular}

\subsubsection{Determination Coefficient $\left(\mathrm{R}^{2}\right)$}

The variance ratio of the endogenous latent variable described as an exogenous latent variable, that is, as shown in [Table 5] the evaluation result of the coefficient of determination $\left(R^{2}\right)$ which means explanatory power. The explanatory power of the Social-relational competence was $29.2 \%$ (adjusted 26.9\%), and the explanatory power of the Project performance was 60.6\%(adjusted 58.9\%). 
Table 5. Determination coefficient $\left(R^{2}\right)$ evaluation result

\begin{tabular}{l|l|l}
\hline Variables & $\mathrm{R}^{2}$ & Adjusted $\mathrm{R}^{2}$ \\
\hline $\begin{array}{l}\text { Social-relational } \\
\text { competence }\end{array}$ & .292 & .269 \\
\hline $\begin{array}{l}\text { Project } \\
\text { performance }\end{array}$ & .606 & .589 \\
\hline
\end{tabular}

\subsubsection{Significance and Suitability of the Path Coefficient}

As shown in [Table 6], to verify the hypothesis of the established research model, structural model analysis was analyzed using the bootstrap of SmartPLS version 3.3.2. Most of the hypotheses were partially accepted, and the results of structural model analysis are shown in [Figure 3] below.

Table 6. Results of Hypothesis test

\begin{tabular}{|c|c|c|c|c|c|}
\hline Hypothesis Path & $\begin{array}{l}\text { path } \\
\text { coefficient }\end{array}$ & $\begin{array}{l}\text { standard } \\
\text { deviation }\end{array}$ & $\begin{array}{l}\text { t- } \\
\text { value }\end{array}$ & $\begin{array}{l}\mathrm{p}- \\
\text { value }\end{array}$ & result \\
\hline Business competence -> Project performance & .327 & .083 & 3.932 & .000 & Accept \\
\hline Technical competence -> Project performance & .264 & .104 & 2.553 & .011 & Accept \\
\hline Values \& Behavior competence -> Project performance & .180 & .096 & 1.880 & .061 & Reject \\
\hline Social-relational competence -> Project performance & .271 & .096 & 2.820 & .005 & Accept \\
\hline Business competence -> Social-relational competence & .059 & .110 & 0.537 & .591 & Reject \\
\hline Technical competence -> Social-relational competence & .285 & .132 & 2.157 & .031 & Accept \\
\hline $\begin{array}{l}\text { Values \& Behavior competence } \rightarrow \text { Social-relational } \\
\text { competence }\end{array}$ & .294 & .133 & 2.214 & .027 & Accept \\
\hline
\end{tabular}

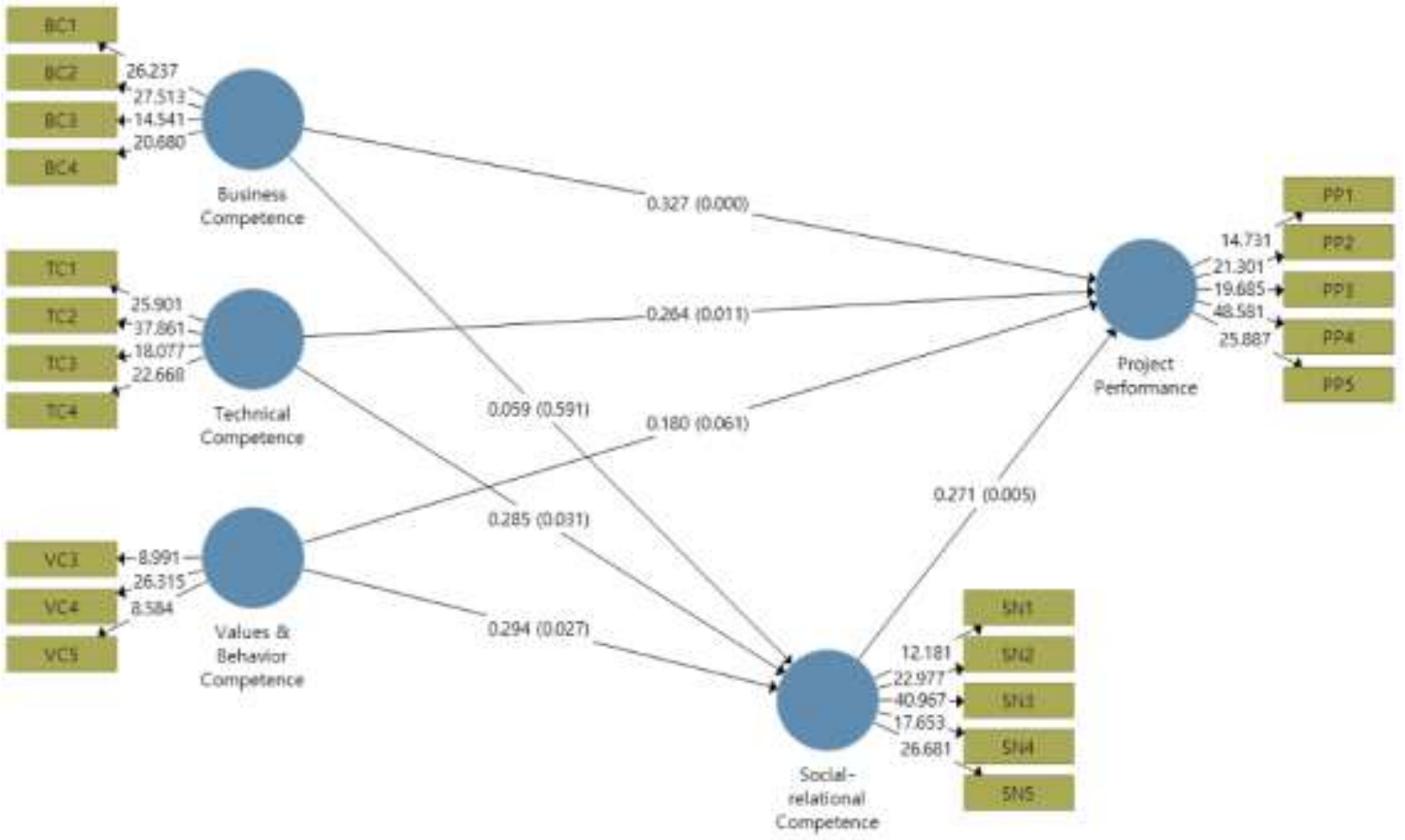

Figure 3. Path Coefficient Analysis 


\subsubsection{Evaluation of Effect size}

The evaluation results of the effect size are shown in [Table 7]. Looking at the value of $\mathrm{f}^{2}$ which contributes to $\mathrm{R}^{2}$ of the endogenous latent variable Project performance is .220 , making the largest contribution in this study case. The $\mathrm{f}^{2}$ that Social-relational competence contributes to $\mathrm{R}^{2}$ of Project performance was.132.

Table 7. Summary of Evaluation Results of Effect size

\begin{tabular}{l|l|l|l|l|l}
\hline Latent Variables & $\begin{array}{l}\text { Business } \\
\text { competence }\end{array}$ & $\begin{array}{l}\text { Technical } \\
\text { competence }\end{array}$ & $\begin{array}{l}\text { Values \& } \\
\text { Behavior } \\
\text { competence }\end{array}$ & $\begin{array}{l}\text { Social- } \\
\text { relational } \\
\text { competence }\end{array}$ & $\begin{array}{l}\text { Project } \\
\text { performance }\end{array}$ \\
\hline $\begin{array}{l}\text { Business } \\
\text { competence }\end{array}$ & & & .004 & .220 \\
\hline $\begin{array}{l}\text { Technical } \\
\text { competence }\end{array}$ & & & .067 & .097 \\
\hline $\begin{array}{l}\text { Values \& Behavior } \\
\text { competence }\end{array}$ & & & & .081 & .050 \\
\hline $\begin{array}{l}\text { Social-relational } \\
\text { competence }\end{array}$ & & & & & .132 \\
\hline
\end{tabular}

\subsubsection{Assessment of Predictive Suitability}

As shown in [Table 8], the results of evaluating predictive suitability. Since $\mathrm{Q}^{2}$ of all endogenous latent variables is greater than 0 , the structural model can be evaluated as having predictive suitability, and these results support the predictive suitability of the structural model for endogenous latent variables.

Table 8. Summary of Assessment of Predictive Suitability

\begin{tabular}{l|l}
\hline Endogenous latent variable & $\mathrm{Q}^{2}$ \\
\hline $\begin{array}{l}\text { Social-relational } \\
\text { competence }\end{array}$ & .189 \\
\hline Project performance & .392 \\
\hline
\end{tabular}

\section{Conclusions}

As shown in the research results, all the competences suggested by the ICMCI competence framework and the Social-relational competence of consultant were found to have a positive effect on Project performance. Among the competences of consultant, Business competence based on insights into customer business and consulting business was found to have the greatest effect on the Project performance. What is unusual that the greater the effect on the Project performance, the smaller the effect on the Social-relational competence. This might mean that consultants with excellent consulting performance neglect social relations as much, and consultants with insufficient consulting performance are more focused on social relations to fill or reinforce the deficiencies. As a professional who solves client's problems based on professional knowledge, the consultant must not only have Business competence and Technical competence, but also Values \& Behavior competence including ethical contents are very important factors. An ethical consultant may lack some competences and may need more time to solve a client's problem, but, because an unethical consultant, even with superior competences, may endanger the entire client's business with unethical thinking and behavior. As a partner in solving the difficulties of SMEs in Korea and as a major stakeholder in maintaining the consulting market, consultants must have all the competence elements related to consulting. In this regard, this study suggests that the ICMCI competence framework, presented as a competence for consultants, can be a milestone for growing into a more specialized consultant.

\section{Acknowledgments}

This research was financially supported by Hansung University. 


\section{References}

[1] McClelland, David C. "Testing for competence rather than for intelligence.".American psychologist 28, no. 1 (1973): 1.

[2] Spencer, Lyle M., and Ph. d Signe M. Spencer. Competence at Work models for superior performance. John Wiley \& Sons, 2008.

[3] Appelbaum, Steven H., and Anthony J. Steed. "The critical success factors in the client-consulting relationship." Journal of management development (2005).

[4] IMC USA's Competency Framework and Certification. Scheme for Certified Management Consultants $^{\mathrm{TM}}\left(\mathrm{CMC}^{\circledR}\right)$. IMC USA (2016). www.imcusa.org.

[5] Choi, P. S. Impact on the Job Satisfaction and Job Performance of Management Consultants Based on ICMCI Competence Model [master's thesis]. Hansung University, Korea (2019). Available from : http://www.riss.kr/link?id=T15067107

[6] Choi, Moon-Sil. "Convergence Study about Awareness toward communication, Communication ability and Self-efficacy: Centered on the 'S' University college students." Journal of Convergence for Information Technology 7, no. 6 (2017): 79-87.

[7] Kim, K. S., and H. Y. Kim. "The effects of empathy education program on children's empathy ability and emotional intelligence." The Journal of Elementary Education 22, no. 4 (2009): 275-300.

[8] Mayer, Roger C., James H. Davis, and F. David Schoorman. "An integrative model of organizational trust." Academy of management review 20, no. 3 (1995): 709-734.

[9] Yoo, H. S. A Study on the Effect of Capability of Consultant on the Consulting Results and Intention for Repurchase: Focusing on the Moderating Effect Depending on the Psychological Characteristics of CEO [master's thesis]. Hansung University, Korea (2015). Available from : http://www.riss.kr/link?id=T13731981

[10] Kerzner, Harold, and Hans Jurgen Thamhain. Project management for small and medium size businesses. Van Nostrand Reinhold, 1984.

[11] Pinto, Jeffrey K., and John E. Prescott. "Planning and tactical factors in the project implementation process." Journal of Management studies 27, no. 3 (1990): 305-327. 